\title{
A Mid-Byzantine Metal Stamp from Bursa Archaeological Museum
}

\author{
Zeynep Sencan ALTINOLUK*
}

An unusual stamp attracted my attention during my work on Byzantine lead seals at Bursa Archaeological Museum ${ }^{1}$. In this study, I will try to understand the place of this stamp in the typology of Byzantine stamping implements and the identity of its owner.

The object is made of a mixture of bronze and lead. Its shape is rectangular and has a length of $11.4 \mathrm{~cm}$, a width of $7.2 \mathrm{~cm}$, and a depth of $1.1 \mathrm{~cm}$. The border of the object is decorated with a margin line that follows the rectangular shape of the object; it includes a 4-line intaglio inscription that begins with a cross (Fig. 1). The retrograde letters certify that the function of the object was stamping. Although no handles are found at the back side of the object, there are two traces which may be interpreted as the points of attachment of a handle (Fig. 2).

The inscription on the front side is given below along with its transcription and translation:
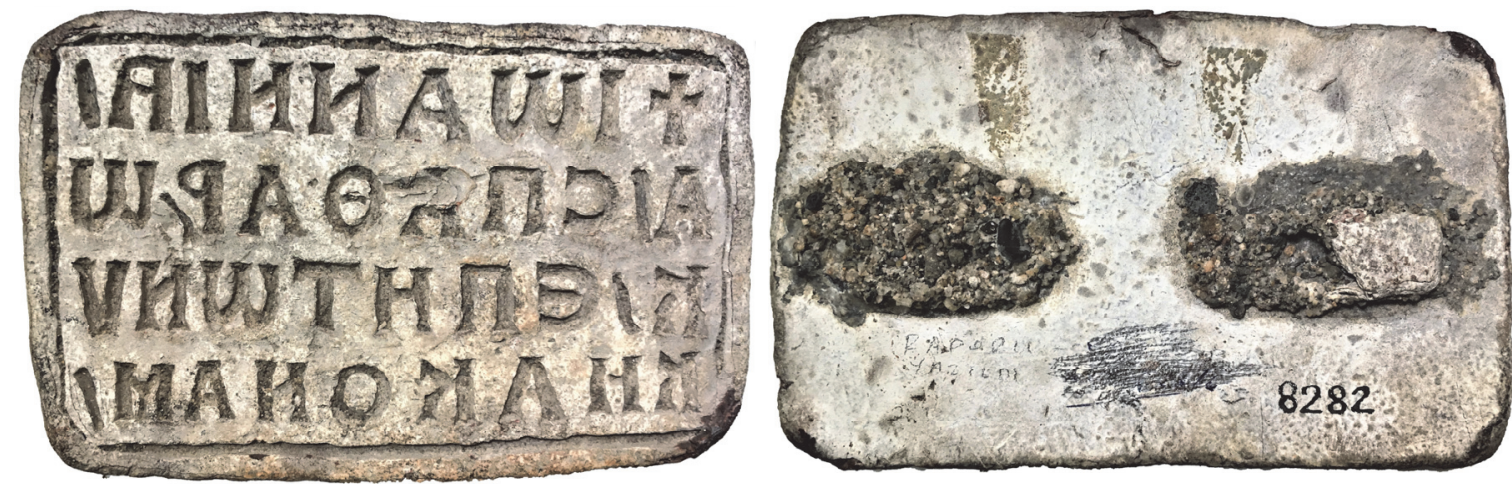

\section{$\dagger$ HWANNIR}

\section{A СПАӨАР $/ \omega$}

$K \in \Pi H T \omega N V$

\section{KHAKONAM}

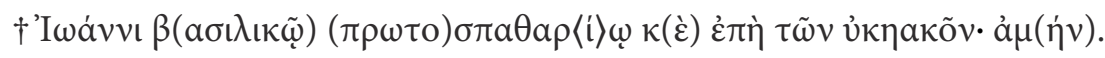

$\dagger$ Iohannes, imperial protospatharios and epi ton oikeiakon: Amen.

\footnotetext{
* Assoc. Prof. Dr. Zeynep Sencan Altınoluk, Çanakkale Onsekiz Mart University, Faculty of Science and Literature, Department of Archaeology, 17100 Çanakkale, Turkey (zsencan@hotmail.com; https:// orcid.org/0000-0003-1769-3766).

${ }^{1}$ The object with inventory no. 8282 was purchased by the museum from Şinasi Çelikkol in 1987. The exact location where the object was found is not specified in the museum records. However, it is known that most of the Bursa Archeology Museum collection comprises of artefacts coming from the Bithynia Region, including Bursa and its surroundings. I would like to thank Jean-Claude Cheynet and Brigitte Pitarakis for sharing their thoughts with me on this object.
} 
Since only the Christian name of the stamp's owner is mentioned in the inscription, it is very difficult to get an idea about the identity of the man who is mentioned. On a lead seal - housed in the collection of the İstanbul Archaeological Museum and dated to the $9^{\text {th }}$ or $10^{\text {th }} \mathrm{c}$. AD - we come across an imperial protospatharios and epi ton oikeiakon named Iohannes ${ }^{2}$. The same name with the same titles appears in the inscription of another seal dated into $10^{\text {th }}-11^{\text {th }} \mathrm{c} .^{3}$. The exact findspots of both of the seals are unknown. It is, however, totally clear that they come from the vicinity of Constantinople.

Although we may be tempted to identify one of the men, who have left behind these seal impressions, as the owner of the stamp, we should keep in mind that Iohannes is one of the most common names in Byzantine prosopography. Therefore, even if the date of one of the seals would match the date of the stamp, it is indispensable to be very cautious in identifying the three bearers of this extremely common name.

Undoubtedly, in particular the temporal classification of the stamp will play an important role in discussing the identity of its owner. Since the functions of such stamps are similar to those of seals and since the formulation of the inscription on this stamp is very close to the wording of the seals, we have to scrutinize the dating criteria for the two seals, in order to gain a solid foundation for bringing them into connection with the stamp.

If we try to date the stamp by its letter forms, one character, that may be revealing, is $m u$, which occurs in the last line of the inscription $(\mathrm{M})$. From the second quarter of the $8^{\text {th }}$ century to the late $13^{\text {th }}$ century, the vertical bars of the letter $m u$ are extended until the line with a short vertical extension ${ }^{4}$. The letter that points to the earliest possible dating is the letter beta which can be found in the first line (R). Before AD 850, in Byzantine lead seals the letter beta was used as double loop (B). After AD 850, the shape of beta changed and was written with a single loop (R). This single loop-beta continued to be used until the last quarter of the $12^{\text {th }}$ century ${ }^{5}$. The letter kappa (K) appearing in the third and fourth lines of the inscription may be indicative for the latest possible dating. In seal inscriptions, the ends of the italic bars of kappa do not appear in horizontal or vertical linear form before the second quarter of the $9^{\text {th }}$ century. From this date until the end of the $11^{\text {th }}$ century, the upper oblique bar of the letter end vertically and the lower oblique bar expires horizontally aligned on the writing line ${ }^{6}$. As beta on the Bursa stamp is single-rounded, the upper and lower curved bars of kappa end with vertical and horizontal lines indicates that this object can be dated sometime between the second half of the $9^{\text {th }}$ century and the late $11^{\text {th }}$ century. On the other hand, on the $6^{\text {th }}-13^{\text {th }}$ century-seals, the epsilon $(\epsilon)$ occurs in a rounded form with horizontal bars, which are generally of equal length. In the $9^{\text {th }}-10^{\text {th }}$ centu-

\footnotetext{
${ }^{2}$ Ebersolt 1914, 387, no. 451: on the obverse of the seal, bust of Virgin Mary with medallion of Christ,

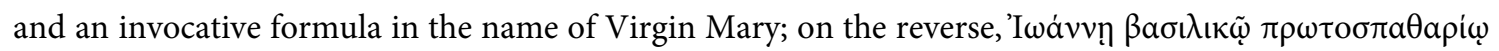

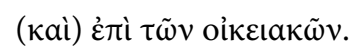

${ }^{3}$ Schlumberger 1884,556 , no. 2: on the obverse of the seal, patriarchal cross on three steps with fleurons arising from the base to the lower traverse bar, and an invocative formula in the name of the Lord; on

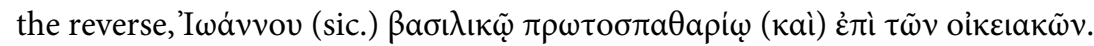

${ }^{4}$ Oikonomidès 1986, 161-162, the table after p. 164.

${ }^{5}$ Zacos - Veglery 1972, xiii, 971; Oikonomidès 1986, 159, the table after p. 164.

${ }^{6}$ Oikonomidès 1986, 161, the table after p. 164.
} 
ries, these three horizontal bars appear to be completely equal in length, ending at a single vertical line ${ }^{7}$. The lines of the epsilon in the third writing line is completely equal, too. Since this form of epsilon appears in every century, it cannot provide us with criteria required to date an inscribed object precisely; Nevertheless, this could be used for strengthening the possibility that an object may be dated into the period of the $9^{\text {th }}-10^{\text {th }}$ centuries.

In order to gain a more accurate dating of the seal, we can also take the abbreviation marks into account. Abbreviation marks on lead seals have shown a particular evolution ${ }^{8}$. The abbreviation sign $(V)$ in the form of a vertical, slanted and straight line, which also occurs in the stamp's inscription, resembles to marks which appear in the middle of the writing line during the late $9^{\text {th }}$ and $10^{\text {th }}$ centuries ${ }^{9}$. The abbreviated word $\dot{\alpha} \mu \eta \dot{v} v$ in the last line of the inscription appears in Byzantine lead seals throughout the Middle Byzantine Period ${ }^{10}$. In inscriptions of this period, the text always begins with an invocation which is in our inscription. Nevertheless, we can still assume that the cross appearing in the very beginning of the stamp inscription may have been understood as a kind of invocation: This cross together with the "am(en)" at the end of the inscription frame the stamp's text.

There are many examples of period-specific misspellings and iotacisms in the inscription: $\dot{\varepsilon} \pi \mathrm{i}$

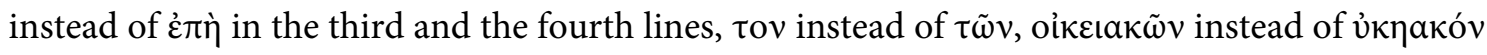
are written. Similarly, on some lead seals, in the writing of the title epi ton oikeiakon, iotacism is observed due to the vowels it includes ${ }^{11}$. The producer of the stamp wrote the text down as it was pronounced in that time, and showed little understanding of historical Greek orthography.

The stamp of the Bursa Museum differs from other metal stamps of the Byzantine Period in some respects. The inscription of this stamp resembles texts, which are written on lead seals and present devotional formulas as well as name, title and office of the seal's owner. While an owner's title mostly does not occur on Byzantine metal stamps, they generally bear a name, no matter whether it is that of a merchant or a producer, and sometimes they may also show religious phrases ${ }^{12}$. Most of the stamps which have survived belong to the early Byzantine Period. These stamps are mostly round, triangular and rectangular or have the shape of a cross, crescent or

\footnotetext{
${ }^{7}$ Oikonomidès 1986, 160, the table after p. 164.

${ }^{8}$ Zacos - Veglery 1972, XIII; Oikonomidès 1986, 158.

${ }^{9}$ These signs, similar to an extended Latin 'S' until the last quarter of the $9^{\text {th }}$ century, have become quite smaller at the end of the $10^{\text {th }}$ century and have become close to resemble a point; then it got longer again. For dating criteria for abbreviation marks in Byzantine lead seals, see: Oikonomidès 1986, 157-158, the table after p. 164.

${ }^{10}$ For examples using ả $\mu \eta \dot{v} v$ in Byzantine lead seals, see: Zacos - Veglery 1972, 3073a-b (the seal of Akylas Hypatos); Classical Numismatic Group, Electronic Auction 72 [12/6/2006], n. 2113; Gorny \& Mosch Giessener Münzhandlung, Auction 152 [10/10/2006], n. 2687.

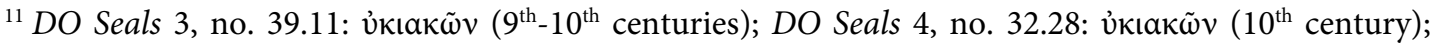

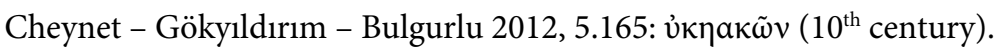

${ }^{12}$ Vikan - Nesbitt 1980, 28; in his article, M. Grünbart provides a literature review of stamping instruments exhibited and published: Grünbart 2006, 14.
} 
foot. Stamps of the Middle Byzantine Period are quite rare and the diversity of forms is much more restricted; stamps from this period are mainly of round or rectangular shape ${ }^{13}$.

Although the forms of seals can offer some valuable clues to dating and determining the functions of stamps, in the case of the Bursa stamp it is a more yielding approach to consider its inscription. According to their inscriptions Michael Grünbart categorises the Byzantine metal stamps into three groups ${ }^{14}$ : The first group comprises stamps that have inscriptions consisting of only one word, most of which are found in the early and late Byzantine periods. The second category is formed by stamps which present inscriptions of more than one word and which may be of religious nature. The stamps of the third group usually bear a name in form of a monogram, in some cases added by some other text. The stamp that we are dealing with belongs to the last group, which also includes some very rare examples of stamps, that bear quite complex inscriptions, showing its owner's office, title and name. They appear in the Middle Byzantine Period. One of these examples that we can compare with the Bursa stamp is that of the logothetes Georgios ${ }^{15}$. The letters carved into this rectangular piece with a size of $4.2 \times 11 \mathrm{~cm}$, is too large to be stamped on a wide surface. This would require the use of excessive pressure to overcome the resistance encountered during stamping. This stamp is thought to be a marking iron used to brand animals ${ }^{16}$. There is some space between the letters as well as outside of the border frame. The gap would reduce the contact of the hot stamp with the animal to be branded, and hence it would minimise the animal's pain. The concave and narrow letters in the Bursa stamp indicate that it was pressed into a soft mass and that it was not a high heated stamp. A rectangular stamp found by Wilhelm Froehner in Constantinople, and now displayed in the Bibliothèque Nationale in Paris belonged to a certain protospatharios Kalokyros ${ }^{17}$. This stamp is dated to the $9^{\text {th }}$ and $10^{\text {th }}$ centuries, since the Kalokyros family was well-known in the $9^{\text {th }}$ century. According to another opinion, it should be dated into the beginning of the $8^{\text {th }}$ century, since genitive and dative forms were mixed together in the legend. Another protospatharios stamp is housed in Paderborn ${ }^{18}$. The inscription of this rectangular stamp, which is smaller than the Bursa stamp, but its design resembles the Bursa stamp very much. The largest known stamp of this group, with the

\footnotetext{
${ }^{13}$ Grünbart 2006, 19.

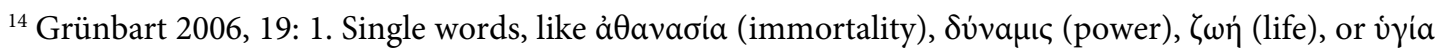

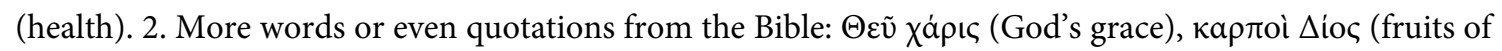

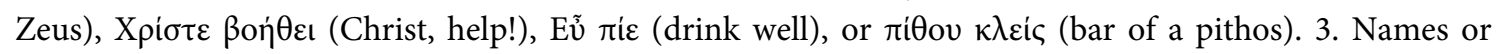
monograms such as $\Theta \omega \mu \tilde{\alpha}$ (of Thomas) or I $\omega \alpha \dot{v} v$ ov (of John).

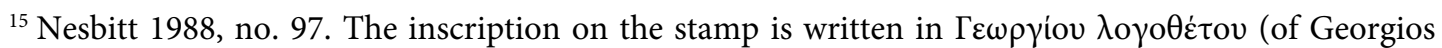
logothetes) in the genitive form.

${ }^{16}$ Grünbart 2005, 100.

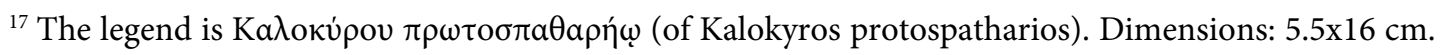
The name of the stamp owner is written in the genitive form and its title in dative form. Because the genitive form tends not to be used on seals after year 700-720 and the dative form starts to be used from the late $7^{\text {th }}$ century onwards, this stamp is dated to the transitionary period between the two forms. Durand 1992, no 224; Caseau 2012, 118-119. Denis Feissel, on the other hand, thinks to date it into the $9^{\text {th }}$ and $10^{\text {th }}$ centuries because the Kalokyros family reached its peak then. Feissel et al. 2001, 16, no. 11. For the place of the Kalokyros stamp among the Byzantine metal stamps, see Grünbart 2005, 103; Grünbart 2006, 20.

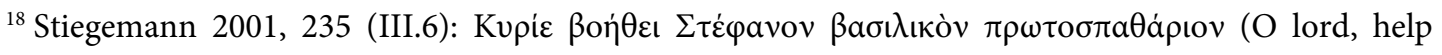
Stephanos, the imperial protospatharios). Dimensions: $5.3 \times 4.3 \mathrm{~cm}$. 
dimensions of $7.5 \times 22 \mathrm{~cm}$ is in the collection of the Getty Museum ${ }^{19}$. Unlike the other stamps, the letters on the surface of this stamp have the form of a relief. This piece, dated into the late $11^{\text {th }}$ or early $12^{\text {th }}$ centuries by John Nesbitt, belonged to the koubouklesios Niketas. Like the Bursa stamp its inscription ends with "amen". A metal stamp dated to the $6^{\text {th }}$ century, found in the Ganei-Hammat (Tiberias) excavation, attracted considerable attention because of its fine style. It resembles the abovementioned rectangular stamps of the Middle Byzantine period ${ }^{20}$. This stamp was found in a cist-tomb together with a stamp of eulogia. This stamp is important because it is found in an archaeological context. In contrast to this special case, for all of the stamps we talked about, including the Bursa stamp, we can develop some ideas about their possible functions, but are unable to reach a definitive conclusion other than that they were used for official and commercial purposes ${ }^{21}$.

There are common questions about the Byzantine metal stamps, which researchers have been trying to explain especially about the function of these objects. We will try to provide an answer to similar questions about the Bursa stamp. Was Iohannes's stamp his personal stamp? Did he use it for his official duties? Wherefore was this stamp made and for stamping which objects was it used?

Trying to answer these questions we have to start with discussing the titles Iohannes had. The first reference is to the office or dignity of a protospatharios, an honorific title Iohannes carried, which means chief imperial guard and chief sword bearer, which is first testified in $718^{22}$; the last instance of reference to this title was considered to date from $1115^{23}$. The post of protospatharios was originally created for the commander of the spatharioi. According to Rodolphe Guilland, protospatharios, whether eunuch or not, probably first appeared in the rank of clarissimus; then later, in an uncertain period, passed to the rank of illustris ${ }^{24}$. While protospatharios until the end of the $7^{\text {th }}$ century described a duty rather than an honour, from the beginning of the $8^{\text {th }}$ century it was awarded to various military and civilian officials as an honorary title $\mathrm{e}^{25}$. In this century, we come across several lead seals which mention strategoi and high civil servants who bear this

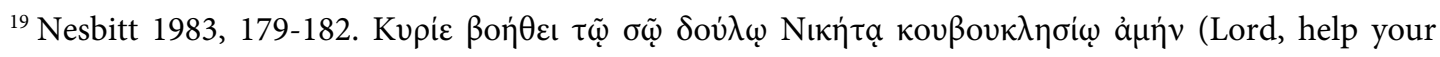
servant Niketas, the koubouklesios, amen).

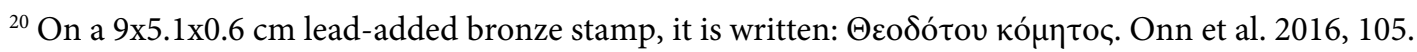

${ }^{21}$ Nesbitt 1983, 182. The assumption that the stamp of Logothetes Georgios was struck on animals, even horses, is perhaps the most obvious approach. Both the structure of the branding technique and the relationship of logothetes with his responsibility of public post and state herds are clues to the function of the stamp.

22 Theophanes 398.7: Sergios, protospatharios and strategos of Sicily; Guilland 1967, 99, corr. in Oikonomidès 1972, 297.

${ }^{23}$ Lemerle 1970, 60.74: Iohannes protospatharios; Kazhdan 1991, 1748. Werner Seibt dates the seal of protospatharios Basil Spondyles to the middle of the $13^{\text {th }}$ century: Seibt 1978 , no. 163 . In the $14^{\text {th }}$ century, Pseudo-Kodinos talked about its place in the palace hierarchy.

${ }^{24}$ Guilland 1955-1957, 649-695, esp. 649.

${ }^{25}$ Guilland 1955-1957, 650.
} 
title ${ }^{26}$. Especially in the $9^{\text {th }}-10^{\text {th }}$ centuries, the title protospatharios, which was associated with

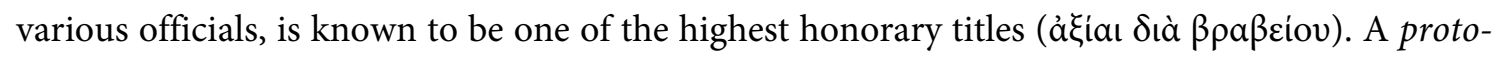
spatharios is a member of the Senate who has personal contact with the emperor. He receives an annual salary (roga) from the emperor himself ${ }^{27}$. In the $10^{\text {th }}$ century, the salary of a protospatharios amounts to 72 nomismata (1 litra of gold) ${ }^{28}$.

The exact meaning of Iohannes's other title, i.e. epi ton oikeiakon, at the end of the $9^{\text {th }}$ century is not precisely understood. The meaning of the term oikeiakos (oikeıкóc) is interpreted as "belonging to the household", "private"29. In the Taktika composed in $9^{\text {th }}-10^{\text {th }}$ century, oikelakoí is used to designate a group of courtiers or servants. It is stated that some oikeiakoi participated in court ceremonies at the Lausiakos, a great hall immediate adjacent the throne hall of the Byzantine emperor ${ }^{30}$. Nicholas Oikonomidès states that epi ton oikeiakon had two different meanings in two different time periods - i.e. in $873 / 4$ and after 1030 - and that the meaning of this title and its functions changed radically in between these two periods. He claimed that the earlier meaning did not express an administrative position; it designated those who were from the emperor's household and was used as a complementary term to some of the honorary titles ${ }^{31}$. According to Oikonomidès, epi ton oikeiakon was created as a special sekreton under the jurisdiction of the logothetes tou genikou in the 10th century ${ }^{32}$. A document from year 994 shows that the sekreton ton oikeiakon was already in existence in the year $972 / 73^{33}$, but not as an independent office. This sekreton administered state-owned properties and collected tax revenues. Probably because he attached special importance to state-owned land, the emperor Basileios II established the office of an epi ton oikeiakon. Its head official managed the financial affairs of the empire and was responsible for the acquisition of new land as well as for the administration of the

${ }^{26} \mathrm{R}$. Guilland stated that the fact that the title was given to, regardless of the strategos, increasingly given to more and more diverse categories of people was confirmed by lead seals. Guilland 1955-1957, 657.

${ }^{27}$ Honorary titles that determined the person's degree of closeness to the emperor also brought an annual salary (roga). The roga was granted for life and could not be inherited: Oikonomidès 2002, 1010. For the roga system, see Lemerle 1967, 77-100.

${ }^{28}$ Lemerle 1967, 88.

${ }^{29}$ Bury 1911, $120 f$.

${ }^{30}$ Oikonomidès 1972, 299; Oikonomidès 1976, 136, no. 65. According to Michel Kaplan, oikeiakos or epi ton oikeiakon, which have a lower status than chrysotriklinos, means having the right to be present at the Lausiakos at the imperial ceremonies. This title, found in many sources before the $11^{\text {th }}$ century, espe-

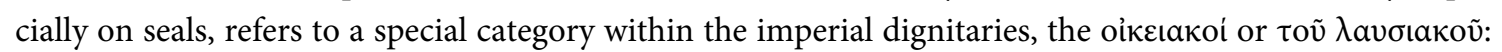
Kaplan 1992, 320.

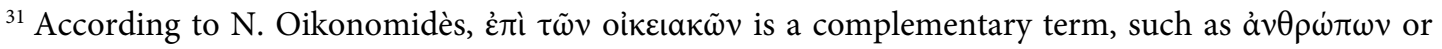
$\kappa \tau \eta \mu \alpha \dot{\tau} \omega v$. This statement accompanies dignities such as protospatharios, primikerios and ostiarios, spatharokandidatos, koubikoularios, spatharios and stratos on a large number of $9^{\text {th }}$ and $10^{\text {th }}$ century lead

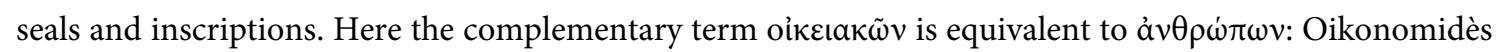
1994, 486-487.

32 Oikonomidès 1976, 136-137; Oikonomidès 1994, 486-89.

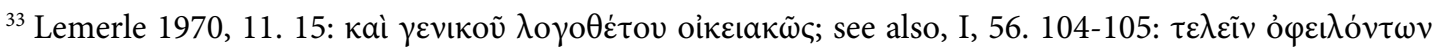

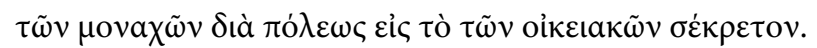


imperial landed property ${ }^{34}$. Many of the epi ton oikeiakon titles which can be found on seals and dated into the $10^{\text {th }}$ century, suggest that they designate an administrative position established well before year 972 and being in charge of different responsibilities of the empire ${ }^{35}$. However, in the late $9^{\text {th }}$ century this sekreton, which was administratively subordinated to the logothetes tou genikou, was not mentioned in the Kletorologion of Philotheos (899). Furthermore, epi ton oikeiakon is also testified together with different offices such as chartoularios, epoptes, krites, proteuon, epeiktes, anagrapheus and kommerkiarios in the $9^{\text {th }}-10^{\text {th }}$ centuries ${ }^{36}$. Most of these offices were concerned with financial affairs of the state such as tax, customs and cadastral control. In 943, Zoetos, a judge in Thessalonica, bears titles of an imperial protospatharios and epi ton oikeiakon. However, Zoetos did not specify his position as a krites that he held in the same year ${ }^{37}$. This example increases the uncertainty which is associated with the use of oikeiakon even further. There may be other examples of office holders who on their seals and in their documents do not specify the particularities of their offices. Leaving this possibility aside, it does not seem convincing to consider every single epi ton oikeiakon, who is mentioned in documents of the $9^{\text {th }}-10^{\text {th }}$ centuries, simply as a dignitary of the imperial palace and to assume that he lived in Constantinople. For example, did the imperial protospatharios, whose seal is dated to the $9^{\text {th }}-10^{\text {th }}$ centuries as well as the epi ton oikeiakon and judge of Opsikion Dionysios ${ }^{38}$ reside in Constantinople or in that thema, where they fulfilled their duties? Despite this uncertainty, when we evaluate the position and social status of Iohannes in the light of the available information - especially the finding place of the stamp -, we are eager to assume that he was primarily a member of the central government. There is no doubt that he has his own properties and assets. At the very beginning Iohannes probably paid more than the amount of his annual salary to win his dignity

\footnotetext{
${ }^{34}$ Oikonomidès 1976, 136-137.

${ }^{35}$ A. Wassiliou and W. Seibt try to find out whether epi ton oikeiakon has any responsibility for the imperial domains in the late $9^{\text {th }}$ century. They also think that epi ton oikeiakon and its different formations on the $9^{\text {th }}-10^{\text {th }}$ century seals cannot be attributed to the imperial palace dignities: Seibt - Wassiliou 2004, 59, no. 31. P. Papadopoulou mentioned Wassilou and Seibt's suggestions about the seal of Kallonas, imperial protospatharios and epi ton oikeiakon, dated to the end of the $9^{\text {th }}$ century; regardless of this uncertainty, she said that Kallonas is a member of the central government: Papadopoulou 2012, 136; Papadopoulou $2019,56$.

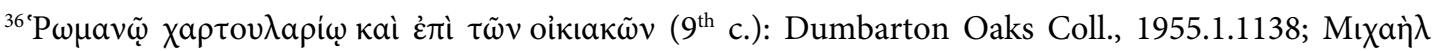

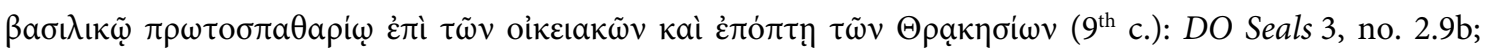

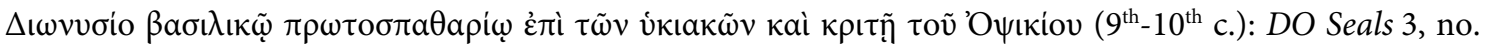

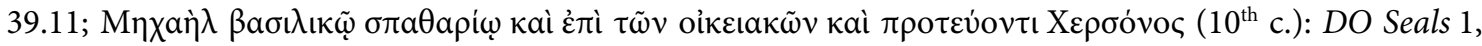

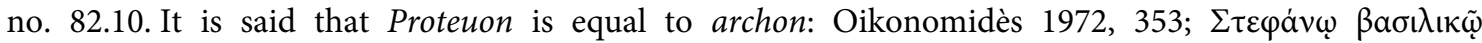

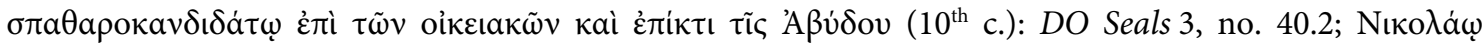

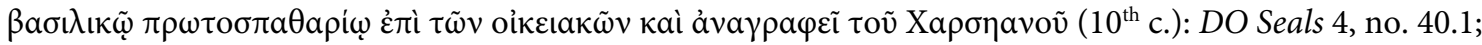

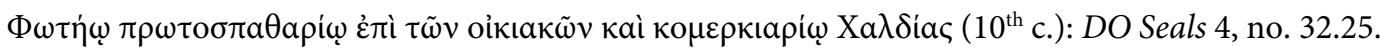

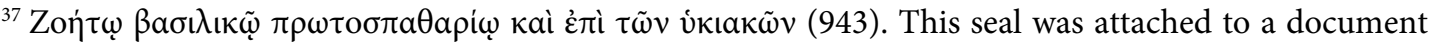
dated to the $2^{\text {nd }}$ of August, 943, and the document also reveals its judicial responsibilities: Papachryssanthou 1975, no. 6; Oikonomidès 1986, 71-72, no. 67; Pagona Papadopoulou stated that this example shows the uncertainty of any speculation regarding the localisation of an epi ton oikeiakon: Papadopoulou 2012, 136; Papadopoulou 2019, 56.
}

${ }^{38}$ DO Seals 3, no. 39.11 . 
in the imperial hierarchy ${ }^{39}$. Moreover, due to the responsibilities of a protospatharios and to the practice of synetheia, he may have distributed a large part of his roga to a variety of individuals such as court employees and people from the clergy ${ }^{40}$. However, his position in the palace should have brought him significant social advantages that outweighed the amount expended.

Trying to understand the fact that Iohannes had become an epi ton oikeiakon we are confronted with difficult questions concering meaning and function of this position. Is this term really an epithet attached to the title of protospatharios, which he uses to emphasize that he is more privileged than other titles? Or does this term, i.e. epi ton oikeiakon, designate an administrative office whose exact function is known since the last quarter of the $10^{\text {th }}$ century? It is difficult to answer this for now. However, in both cases, we can make some assumptions by basing on the fact that his stamp was found in Bithynia.

It is known that in the Byzantine Empire of the $9^{\text {th }}$ century large amounts of land in the capital and the countryside belonged to aristocrats. Inscriptions found in Skripou (Orchomenos, motherland Greece) and dated to year 873/4 imply that the epi ton oikeiakon Leon, a church founder and protospatharios of the empire possessed large pieces of lands in Boeotia and had established a career thanks to the honorary title he obtained from the emperor ${ }^{41}$. When we compare Iohannes with Leon who bore the same titles, we may speculate that Iohannes owns lands in the Bithynia region, too. From the second half of the $8^{\text {th }}$ century onwards, aristocrats residing in Constantinople, especially due to its convenient access by sea, acquired extensive real estate on the other side of the coast, i.e. in Bithynia ${ }^{42}$. There was an expansion of properties of aristocrats in the $10^{\text {th }}$ century. Jean-Claude Cheynet states that the geographical distribution of the Constantinopolitan aristocraty's assets concentrated in Bithynia and Western Asia. This became a familiar situation in the $11^{\text {th }}$ century, but the beginnings can be traced back to a rather earlier date ${ }^{43}$. Monastery property, mostly gathered from aristocratic wealth, can be proven in Bithynia throughout the Middle Byzantine Period. When we examine Bithynian monasteries, we come across people who previously held offices related to financial affairs but then decided to move to Bithynia to lead an ascetic life ${ }^{44}$.

${ }^{39}$ Oikonomidès 1997,205 ; Oikonomidès 2002 , 1010. In the $10^{\text {th }}$ century, the person who wanted to become protospatharios had to pay 1296 nomismata (18 litrai of gold): De cer., 1, 692.

${ }^{40}$ At the end of the $9^{\text {th }}$ and the $10^{\text {th }}$ centuries, dignitaries had to pay synetheiai ( $\sigma u v \eta \dot{\theta} \theta \varepsilon$ al) to their colleagues at the festival celebrations: Oikonomidès 1972, 88, no. 28.

${ }^{41}$ Different views have been reported for the meaning of the term epi ton oikeiakon held by Leon. For example, M. Sotiriou and A. H. S. Megaw have argued that Leon was in charge of the administration of the imperial domains in Greece, in the service of the emperor: Sotiriou 1931, 157; Megaw 1966, 23-25; Nicholas Oikonomidès, stating that the sekreton of epi ton oikeiakon was not established before the $11^{\text {th }}$ century, they contested these ideas: Oikonomidès 1994, 485-485. See also Prieto Domínguez 2013, 166191 for the founder of the Skripou church.

${ }^{42}$ Cheynet 2000, 300.

${ }^{43}$ Cheynet 2000, 301.

${ }^{44}$ Theophanes "the Confessor" became a strator in the time of Emperor Leo IV (AD 775/780) and was assigned to Kyzikos with a mission; later he got the title of spatharios; At the end of AD 780, he founded

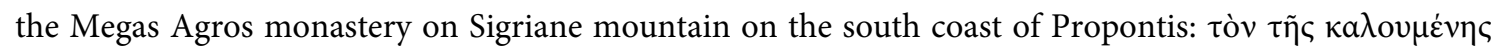

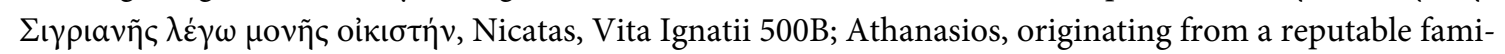
ly from Constantinople, was commissioned as grapheus to the department of logothesion by his father in 
The imperial protospatharios and epi ton oikeiakon Nikephoros Erotikos from the $10^{\text {th }}$ century, founder of a monastery for older people on the mountain of Tmolos, provides a good example in this regard even though it was in a different geographical area, i.e. in Lydia, ${ }^{45}$. It is also possible that Iohannes, wealthy and well-able to finance the construction of a monastery, was also likely to be the founder of a monastery in Bithynia or a donour. Unfortunately, there is no other evidence to support this claim.

It is possible that Iohannes may have used his stamp for certain purposes on his own property, but it should also be taken in consideration that he employed it in his role as an administrator of the sekreton of oikeiakon. If the latter is the case, he may have used this stamp in the management of imperial property or within the supply of various goods for the imperial court ${ }^{46}$. It is, however, also perfectly reasonable that he used this stamp on his own estate - no matter whether it was located in the capital or in Bithynia - or for donations. As we have already taken into account the stamp may have been applied on a soft material such as clay. The fact that the stamp is large in size and bears a personal inscription contradicts the idea that it was employed for stamping Eucharistic bread. It makes more sense to identify it as a brick stamp; in this context, however, we should not completely overlook the possibility that it could have also been stamped on bigger pithoi or other clay objects. It is a continuing tradition since the Roman Imperial Period that bricks were marked. From the $6^{\text {th }}$ century onwards they may bear the name of the person or the entity who ordered them ${ }^{47}$. It is thought that such stamps could bear the name of the employer and that they were marked by the workers in the workshop that manufactured those bricks ${ }^{48}$; thereby, the stamps enabled the workers to verify the level of production in order to receive the adequate wages.

It is considered that the owners of brickyards donated a part of their production and stamped it in order to emphasise their ranks, dignities and offices ${ }^{49}$. For this reason we may also consider that Iohannes's stamp may have been used for marking objects which he wanted to donate and which by means of their stamped inscriptions should keep his memory alive.

I am only too well aware that this stamp raises more questions than we are able to answer with certainty. The time had not yet come to give definitive answers and, therefore, I see this paper only as a further step towards a better understanding of these still puzzling objects.

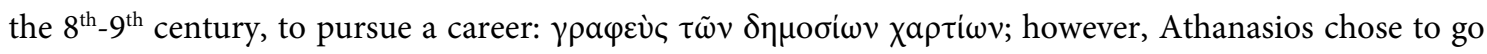
to Pelekete monastery in Bithynia and received high titles there: PBE I, "Atanasios 5". For Bithynian monasticism as centered around Mount Olympos, see Menton 1935.

${ }^{45}$ Drew-Bear - Koder 1988, 197-215; Thomas - Hero 2000, 310, 312, no: 16: Mount Tmolos: Typikon of Nikephoros Erotikos for the Monastery of the Mother of God and the Old Age Home called Ta Derma on Mount Tmolos.

${ }^{46}$ Grünbart 2005, 104.

${ }^{47}$ Bardill 2004, 16; Caseau 2012, 119.

${ }^{48}$ Jonathan Bardill stated that in accordance with the locatio conductio contract, the officinator manufacturing the bricks may have wanted to guarantee the payment by urging his workers to stamp a portion of the bricks to be delivered in the name of the dominus who placed the order: Bardill 2004, 19. The Digest 18.1 65 explains that the manufacture of bricks was organized according to a locatio-conductio contract, whereby the owner of the land (dominus/locator) on which the clay quarries were located agreed to pay a contractor (officinator/conductor) for the conversion of his clay into bricks.

${ }^{49}$ Gedeon 1892, 381-382; Dorigny 1876, 83; Mango 1950, 25. 


\section{Bibliography}

Bardill 2004

Bury 1911

Caseau 2012

Cheynet - Gökyıldırım Bulgurlu 2012

Cheynet 2000

Dorigny 1876

Drew-Bear - Koder 1988

Durand 1992

Ebersolt 1914

Feissel et al. 2001

Gedeon 1892

Grünbart 2005

Grünbart 2006

Guilland 1955-1957

Guilland 1967

Kaplan 1992

Kazhdan 1991

Lemerle 1967
J. Bardill, Brickstamps of Constantinople, vol. 1, Oxford 2004.

J. B. Bury, The Imperial Administrative System in the Ninth Century, London 1911.

B. Caseau, Magical Protection and Stamps in Byzantium, in: I. Regulski et al. (eds.), Seals and Sealing Practices in the Near East: Developments in Administration and Magic from Prehistory to the Islamic Period, Leuven 2012, 115-132.

J. C. Cheynet - T. Gökyıldırım - V. Bulgurlu, Les Sceaux Byzantins du Musee Archeologique d'Istanbul, İstanbul 2012.

J. C. Cheynet, L'aristocratie byzantine (VIIIe-XIIIe siècle), Journal des Savants 2, 2000, 281-322.

A. S. Dorigny, Inscription Céramiques Byzantines, Revue Archéologique 32, 1876, 82-95.

Th. Drew-Bear - J. Koder, Ein byzantinisches Kloster am Berg Tmolos, JÖB 38, 1988, 197-215.

J. Durand (ed.), Byzance: L'art byzantin dans les collections publiques françaises, Paris 1992.

J. Ebersolt, Sceaux byzantins du Musée de Constantinople, RN 4/18, 1914, 207-243, 377-409.

D. Feissel - C. Morrisson - J. -C. Cheynet - B. Pitarakis (eds.), Trois donations byzantines au Cabinet des médailles: Froehner (1925), Schlumberger (1929), Zacos (1998), Paris 2001.

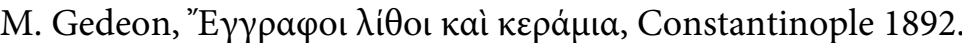

M. Grünbart, Verbreitung und Funktion byzantinischer Metallstempel, in: C. Ludwig (ed.), Siegel und Siegler. Akten des 8. Internationalen Symposions für byzantinische Sigillographie (Berliner Byzantinistische Studien 7), Frankfurt am Main 2005, 95-104.

M. Grünbart, Byzantine Metal Stamps in a North American Private Collection, Dumbarton Oaks Papers 60, 2006, 13-24.

R. Guilland, Études sur l'histoire administrative de l'empire byzantin. Les titres auliques des eunuques: Le protospathaire, Byzantion 25-27, 1955-1957, 649-695.

R. Guilland, Recherches sur les institutions Byzantines, 2 vols, Amsterdam 1967.

M. Kaplan, Les hommes et la terre à Byzance du VI ${ }^{\mathrm{e}}$ au XI ${ }^{\mathrm{e}}$ siècle: propriété et exploitation du sol, Paris 1992.

A. P. Kazhdan (ed.), Oxford Dictionary of Byzantium, Oxford 1991.

P. Lemerle, Roga et rente d'état aux Xe-XIe siècles, REB 25, 1967, 77-100. 
Lemerle 1970

Mango 1950

Megaw 1966

Menthon 1935

Nesbitt 1983

Nesbitt 1988

Oikonomidès 1972

Oikonomidès 1976

Oikonomidès 1986

Oikonomidès 1994

Oikonomidès 1997

Oikonomidès 2002

Onn et al. 2016

Papachryssanthou 1975

Papadopoulou 2012

Papadopoulou 2019

Prieto Domínguez 2013
P. Lemerle (ed.), Actes de Lavra, Vol. 1, Des origines à 1204, Paris 1970.

C. A. Mango, Byzantine Brick Stamps, AJA 54/1, 1950, 19-27.

A. H. S. Megaw, The Skripou Screen, The Annual of the British School at Athens 61, 1966, 1-32.

B. Menthon, L'Olympe de Bithynie, Paris 1935.

J. W. Nesbitt, A Mid-Byzantine Bronze Stamp in the Getty Museum, The J. Paul Getty Museum Journal 11, 1983, 179-182.

J. W. Nesbitt, Byzantium. The Light in the Age of Darkness, in: J. T. Spike - M. Koortbojian (eds.), Exhibition Catalogue, Ariadne Galleries, New York 1988.

N. Oikonomidès, Les listes de préséance byzantines des IXe et Xe siècles, Paris 1972.

N. Oikonomidès, L'évolution de l'organisation administrative de l'empire byzantin au XIe siècle (1025-1118), Travaux et Mémoires 6, 1976, 126-152.

N. Oikonomidès, Collection of Dated Byzantine Lead Seals, Washington DC 1986.

N. Oikonomidès, Pour une nouvelle lecture des inscriptions de Skripou en Béotie, Travaux et Mémoires 12, 1994, 479-494.

N. Oikonomidès, Title and Income at the Byzantine Court, in: H. Maguire (ed.), Byzantine Court Culture from 829 to 1204, Washington DC 1997, 199-215.

N. Oikonomidès, The Role of the Byzantine State in the Economy, in: A. E. Laiou (ed.), The Economic History of Byzantium. From the Seventh through the Fifteenth Century, vol. 1, Washington DC 2002, 973-1058.

A. Onn - Sh. Weksler-Bdolah - L. Di Segni, A Byzantine Stamp Seal of "Theodotos the Comes" from Ganei-Hammat (Tiberias), in: J. Patrich - O. Peleg-Barkat - E. Ben-Yosef (eds.), Arise, Walk Through the Land. Studies in the Archaeology and History of the Land of Israel in Memory of Yizhar Hirschfeld on the Tenth Anniversary of his Demise, Jerusalem 2016, 101-110.

D. Papachryssanthou, Actes du Protaton, Paris 1975.

P. Papadopoulou, Five Lead Seals from Byzantine Butrint, in: J.-C. Cheynet - C. Sode (eds.), Studies in Byzantine Sigillography, vol. 11, Berlin 2012, 133-142.

P. Papadopoulou, Lead Seals, in: S. Greenslade (ed.), Butrint 6: Excavations on the Vrina Plain vol. 2: The Finds, Oxford; Philadelphia 2019, 55-58.

O. Prieto Domínguez, On the Founder of the Skripou Church: Literary Trends in the Milieu of Photius, Greek, Roman and Byz- 
Schlumberger 1884

Seibt 1978

Seibt - Wassiliou 2004

Sotiriou 1931

Stiegemann 2001

Thomas - Hero 2000

Vikan - Nesbitt 1980

Zacos - Veglery 1972 antine Studies 53, 2013, 166-191.

G. Schlumberger, Sigillographie de l'Empire byzantin, Paris 1884 .

W. Seibt, Die byzantinischen Bleisiegel in Österreich, vol. 1, Kaiserhof, Vienna 1978.

W. Seibt - A. -K. Wassiliou, Die byzantinischen Bleisiegel in Österreich, vol. 2, Zentral- und Provinzialverwaltung, Vienna 2004.

M. G. Sotiriou, Ho naos tes Skripous tes Boiotias, Archaiologike ephemeris: ekdidomene tes archaiologikes hetaireias 77, 1931, 119157.

C. Stiegemann (ed.), Byzanz. Das Licht aus dem Osten. Kult und Alltag im Byzantinischen Reich vom 4. bis 15. Jahrhundert. Katalog der Ausstellung im Erzbischöflichen Diözesanmuseum Paderborn, Mainz 2001.

J. Thomas - A. C. Hero (ed.), Byzantine Monastic Foundation Documents: A Complete Translation of the Surviving Founders' Typika and Testaments, vol. 1, Washington DC 2000.

G. Vikan - J. Nesbit, Security in Byzantium: Locking, Sealing, and Weighing, Dumbarton Oaks. Byzantine Collection. Publications, no. 2, Washington DC 1980.

G. Zacos - A. Veglery, Byzantine Lead Seals, I/3, Basel 1972.

\section{Bursa Arkeoloji Müzesi'nden Bir Orta Bizans Damgası \\ Öz}

Bu makale Bursa Arkeoloji Müzesi koleksiyonunda yer alan Orta Bizans Dönemi’ne ait bir metal damganın Bizans baskı tipolojisi içindeki yeri ve sahibinin kimliğini belirlemeye çalışmaktadır. Bu makalede ele aldığımız damga, yazıtın sahibinin adının, taşıdığı görev ve unvanların belirtildiği nadir örneklerden biridir. Yaklaşı 9.-10. yüzyıllara tarihlenen damganın sahibi, imparatorluk protospatharios'u ve epi ton oikeiakon olan Iohannes'tir. Protospatharios unvanından, Iohannes'in merkezi yönetimin bir üyesi ve varlıklı bir aristokrat olduğu anlaşılmaktadır. Iohannes ile birlikte görülen epi ton oikeiakon, onun diğer görevlilerden daha ayrıcalıklı bir birey ve saray halkından olabileceğini gösteren bir unvan olabilir. Diğer yandan, 10. yüzyllın son çeyreğinden itibaren oikeiakon sekreton'luğu altında idari bir görevin varlığını da biliyoruz. Bunun ışı̆̆ında, şu soruya sahibiz: Iohannes damgasını kişisel işleri için mi kullandı veya imparatorluk mülklerinin yönetimindeki idari pozisyonuna uygun olarak mı kullandı? Her iki durumda da, damgasının kil gibi yumuşak bir obje üzerine basıldığını ve bunun bir tuğla damgası olabileceğini düşünüyoruz.

Anahtar Sözcükler: Bursa, Bithynia, Bizans metal damgası, protospatharios, epi ton oikeiakon. 


\section{A Mid-Byzantine Metal Stamp from Bursa Archaeological Museum}

\section{Abstract}

This article tries to determine the place and identity of the owner of a metal stamp located in the Bursa Archaeological Museum collection in the Byzantine stamping objects typology. The stamp that we consider in this article is one of the rare examples, in which the inscription specifies the name of the owner as well as the offices and titles he held. The owner of the stamp, dated to approximately $9^{\text {th }}-10^{\text {th }}$ centuries, is Iohannes, the imperial protospatharios and epi ton oikeiakon. It is understood from the title protospatharios that Iohannes was a member of the central government and a wealthy aristocrat. The title epi ton oikeiakon, appearing together with Iohannes, may be a title that shows that he is a more privileged individual than other officials and that he may be from the imperial court. On the other hand, we also know of an administrative task under the sekreton of oikeiakon since the last quarter of the $10^{\text {th }}$ century. In light of this, we have the following question: did Iohannes use his stamp for his personal affairs or did he use it in accordance with his responsibilities, which were part of his administrative position of management of imperial properties? In either case, we think that his stamp was stamped on a soft object such as clay and that it may be a brick stamp.

Keywords: Bursa, Bithynia, Byzantine metal stamp, protospatharios, epi ton oikeiakon.

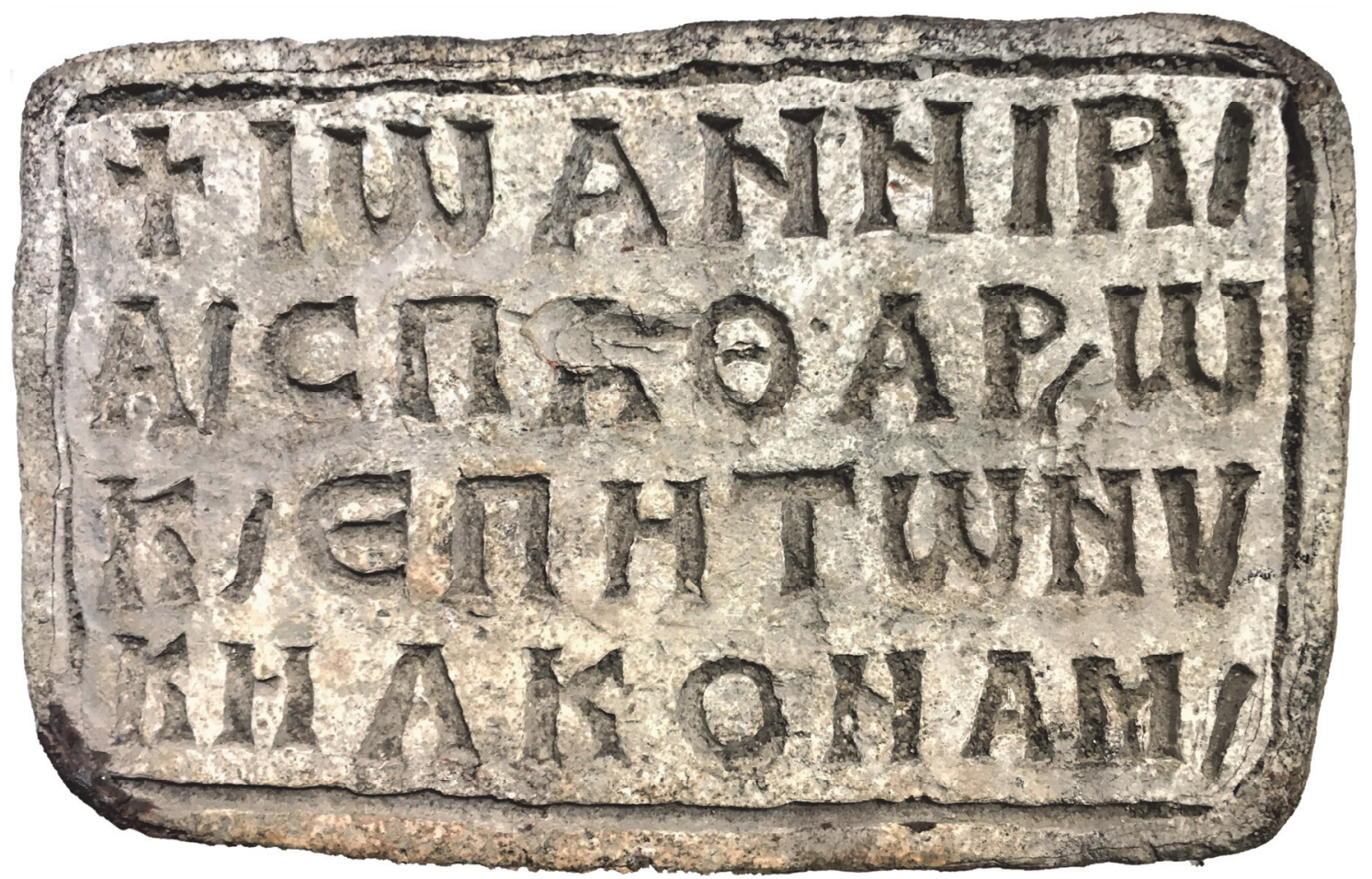

Revers image of the seal. 